\title{
Critic still lays blame for AIDS on lifestyle, not HIV
}

London. Haemophiliacs who have died of AIDS after being given blood infected with HIV have probably succumbed to "a whole lot of things that could be described as AIDS", rather than the virus itself, according to Kary Mullis, the Californian chemist who is backing the London Sunday Times' campaign against what it describes as the "HIV myth".

Speaking in London last week, Mullis also suggested that the deaths of HIVpositive children were in fact caused by their treatment with the drug AZT. And the epidemic of AIDS in Africa, which he disbelieved, was probably the result of misleading AIDS tests due to a cross-reaction with malaria antibodies; "most Africans have antibodies to malaria which look like antibodies to AIDS."

According to Mullis, the only genuine cases of AIDS have been those in the gay community in centres such as San Francisco and New York. The disease, he said, is probably the result of the breakdown of the immune system following exposure to a wide collection of retroviruses accumulated through multiple contacts in bath houses.

But the idea that HIV was the "probable cause of AIDS" was not a scientifically proven fact, he said. Nor, indeed, was there any clear evidence that AIDS was spread through sexual contact. "I think we [spread] retroviruses by our lungs, not by our genitals," said Mullis, who was awarded last year's Nobel prize for chemistry for his invention of the polymerase chain reaction (PCR) technique.

Mullis gave his views, which are eyed sceptically by most members of the scientific community, to a meeting organized by the newspaper entitled "Why there is still an HIV-AIDS controversy".

In common with others who claim that HIV has wrongly been identified as the "probable cause" of AIDS, such as the molecular biologist Peter Duesberg, he claimed supporters of this "hypothesis" are primarily motivated by financial and career ambitions.

Mullis said his own scepticism stemmed from an inability to find a single widelyaccepted scientific citation for the statement - which he himself used in papers describing the use of PCR for detecting HIV - that HIV is the probable cause of AIDS.

Modern science is based on the ability to demonstrate facts to an audience, however sceptical, he said. Any postgraduate student who had written a convincing paper demonstrating that HIV "causes" AIDS would be credited with having published "the paper of the century", he said.

Mullis's remarks received enthusiastic support from several members of the audience, who expressed their own criticism of the "establishment" handling of the AIDS crisis. But scientists in the audience remained deeply sceptical. Tim Oliver, a cancer physician, questioned Mullis's statement that HIV-positive haemophiliacs have died of AIDS for reasons unrelated to their exposure to the virus. He was unconvinced by Mullis' reply.

Many scientists had rejected invitation from the Sunday Times to attend the meeting. Robin Weiss, for example, director of research at the Institute of Cancer Research, wrote that Mullis "has about as much knowledge and authority to speak on the cause of AIDS as William Shockley, the Nobel Laureate who invented the transistor, had when he used to speak on the intellectual superiority of whites compared to blacks."

Mullis himself appeared unfazed by such criticisms. His main concern was that the efforts of "a lot of talented people in the medical profession had been diverted" by misconceptions about HIV. "It is not a scientific fact, or even a supposed fact, that HIV is the probable cause of AIDS," he said, unrepentant in the face of those who complained his ideas were undermining the activities of AIDS health-workers around the world.

David Dickson

\section{New rules on CERN membership 'essential'}

London. A change in the rules allowing physicists from countries that are not members of the European Laboratory for Particle Physics (CERN) in Geneva to participate in experiments at the laboratory is essential if international agreement is to be reached on the funding of the proposed Large Hadron Collider (LHC), according to a report published this week by the UK Parliamentary Office of Science and Technology.

At present, foreign physicists are able to work at CERN, even though contribut- ing little to its cost, in exchange for access by Europeans to their own machines. But given the decline in state-of-the art accelerators, continuing present arrangements is "not an option", says the report.

Keeping the status quo would mean that "Japan, America, Canada, China, India and other non-members would be heavily subsidized". The future success of CERN will depend on finding a way of encouraging non-member states to participate in CERN "on a more equitable basis", says the report.

\section{Lay panel sought to give verdict on 'engineered' plants}

London. A search was launched last week for 15 "very special 'ordinary' people", to make up a lay panel to give its views on behalf of the British public on the use of genetic engineering in plants. Panel members will be recruited through advertisements on local radio and in regional newspapers.

Britain's first 'consensus conference' is being funded by the Biotechnology and Biological Sciences Research Council (BBSRC) and organized by the Science Museum in London. It is based on procedures developed in Denmark, where they have been used by the Danish Board of Technology in fields such as food irradiation and mapping of the human genome.

Volunteers must have no vested interest in biotechnology, but must be interested in the social and ethical implications of its use. They must also be willing to give up at least three weekends to the project, for which they will receive only expenses.

During the first weekend, members of the panel will be given basic information about plant biotechnology, enabling them to identify areas of concern. At a second meeting, the panel will prepare written questions to be put to a pool of experts.

The process will end with a public conference at the beginning of November at which members of the panel will crossexamine the selected experts directly. The lay panel will then prepare a report summarizing its views.

"We feel that 15 panel members will provide sufficient scope to bring diversity of background and experience," says George Gaskell, senior lecturer in social psychology at the London School of Economics, who is responsible for the selection of members of the lay panel.

John Durant, assistant director of the Science Museum, and a member of the project's steering committee, said interest has already been expressed in a similar consensus conference looking at biotechnology in medicine and genetics.

The BBSRC has contracted the organization of the process to the Science Museum to avoid criticism that the project is an industry set-up. For the same reason, it has been keen to balance the members of the steering committee, which will include both a senior executive from Zeneca Seeds, and Harriet Kimble, senior deputy chairman of the Consumers Association.

According to Kimble, the procedure is intended to reduce the chances of new genetically engineering products being rejected by consumers by ensuring that they feel they have been properly consulted beforehand.

Maggie Verral 